\title{
Production of glucose and fructose syrups from cassava (Manihot esculenta Crantz) starch using enzymes produced by microorganisms isolated from Brazilian Cerrado soil
}

\author{
Produção de xaropes de glicose e de fructose a partir de amido de mandioca (Manihot esculenta Crantz) \\ usando enzimas produzidas por microorganismos isolados do solo de Cerrado Brasileiro
}

\author{
Roberto do Nascimento SILVA ${ }^{1}$, Fábio Pereira QUINTINO², \\ Valdirene Neves MONTEIRO ${ }^{3}$, Eduardo Ramirez ASQUIERI ${ }^{2 *}$
}

\begin{abstract}
The high demands for sugars and the development of enzymatic technology have increased the production of sweeteners, especially for glucose and fructose syrups. This work describe a technology for glucose and fructose syrups from Brazilian cassava starch using enzymes produced by soil microrganisms isolated from the Brazilian Cerrado soil. Firstly, Aspergillus niger and Streptomyces sp. were isolated from the soil and used as glucoamylase (GA) and glucose isomerase (GI) producer sources. After characterization, GA and GI exhibited optimum $\mathrm{pH} 4.5$ and 8.0 , respectively. GA showed maximum activity at $60^{\circ} \mathrm{C}$ and GI at $85^{\circ} \mathrm{C}$. GA and GI retained 65 and $80 \%$, respectively, of initial activity after 180 minutes of incubation at $60^{\circ} \mathrm{C}$. The kinetic parameters $\mathrm{K}_{\mathrm{m}}$ and $\mathrm{V}_{\text {máx }}$ were $0.476\left(\mathrm{mg} \cdot \mathrm{mL}^{-1}\right.$ ) and 8.58 ( $\mu \mathrm{mol} / \mathrm{minute}$ ) for $\mathrm{GA}$ and $0.082(\mathrm{M})$ and 48.20 ( $\mu \mathrm{mol} /$ minute) for GI. The maximum glucose syrups production occurred after 24 hours of reaction with a $98 \%$ yield. The production of fructose syrups with $42 \%(\mathrm{w} / \mathrm{v})$ was reached after 96 hours of reaction.

Keywords: glucoamylase; glucose isomerase; glucose-fructose syrups; cassava.
\end{abstract}

\section{Resumo}

A alta demanda por açúcares e o desenvolvimento da tecnologia enzimática têm aumentado a produção de adoçantes, principalmente xaropes de glicose e frutose. Este trabalho descreve uma tecnologia para a produção de xaropes de glicose e frutose a partir de amido de mandioca usando enzimas produzidas por microrganismos isolados do solo do Cerrado Brasileiro. Primeiramente, Aspergillus niger e Strepotmyces sp. foram isolados a partir do solo e usados como fontes produtoras de glicoamilase (GA) e glicose isomerase (GI). Após caracterização GA e GI exibiram $\mathrm{pH}$ ótimo de 4,5 e 8,0, respectivamente. GA apresentou uma atividade máxima a $60{ }^{\circ} \mathrm{C}$ enquanto que GI a $80^{\circ} \mathrm{C}$. GA e GI mantiveram 65 e $80 \%$, respectivamente, da atividade inicial, após 180 minutos de incubação a $60^{\circ} \mathrm{C}$. Os parâmetros cinéticos $\mathrm{K}_{\mathrm{m}} \mathrm{e} \mathrm{V}_{\text {máx }}$ foram 0,476 (mg $\mathrm{mL}^{-1}$ ) e 8,58 $\left(\mu \mathrm{mol} \mathrm{min} \mathrm{m}^{-1}\right.$ ) para GA e 0,082 (M) e 48,20 ( $\left.\mu \mathrm{mol} \mathrm{min}^{-1}\right)$ para GI. A máxima produção de xarope de glicose ocorreu após 24 horas de reação com um rendimento de $98 \%$. A produção de xarope de frutose com $42 \%(\mathrm{~m} / \mathrm{v})$ foi alcançada após 96 horas de reação.

Palavras-chave: glicoamilase; glicose isomerase; xarope de frutose; mandioca.

\section{Introduction}

Corn starch is the major industrial raw material for glucose and fructose syrup production in the US and in many other parts of the world (CABELLO, 1999). However, good results have been obtained for starch processing in Europe, South America and Asia when alternative starch sources are used (SCHENCK; HEBEDA, 1992). The industrial processing of starch to sugars can be carried out either by acid or enzymatic hydrolysis. However, the use of enzymes is preferred to acid, once it produces high yields of desired products and less formation of undesired products such as toxics compounds (SANJUST et al., 2004). In recent years, biological approaches using enzymes in starch processesing have been extensively studied to obtain high- purity sugars from starch. These processes became economically attractive for biotechnological industries (VORAGEN, 1998; PARK et al., 2005). Furthermore, with the current worldwide increased sugar demand, a new research era in enzymatic technology has concentrated on decreasing the high costs of syrup production (SANJUST et al., 2004; VORAGEN, 1998).

The glucose and fructose syrup are commonly produced by processing corn starch (VORAGEN, 1998). First, corn starch is treated with alpha-amylase to produce oligosaccharides. Next, an enzyme called glucoamylase (GA) breaks down the sugar chains even further to yield the simple sugar glucose

\footnotetext{
Recebido para publicação em 3/4/2008

Aceito para publicação em 3/1/2009 (003383)

Laboratório de Enzimologia, Instituto de Ciências Biológicas, Universidade Federal de Goiás, CEP 74001-940, Goiânia - GO, Brazil

2 Laboratório de Tecnologia e Bioquímica de Alimentos, Faculdade de Farmácia, Universidade Federal de Goiás, CEP 74001-940, Goiânia - GO, Brazil,

E-mail: asquieri@gmail.com

${ }^{3}$ Laboratório de Bioquímica de Microrganismos, Unidade Universitária de Ciências Exatas e Tecnológicas da Universidade Estadual de Goiás - UnUCET/UEG, BR 153,

Km 98, Campus Henrique Santillo, CEP 75000-000, Anápolis - GO, Brazil

${ }^{*}$ A quem a correspondência deve ser enviada
} 
(PONTOH; LOW, 1995). Finally glucose-isomerase (GI) converts glucose to a mixture of about 26 to $59 \%$ of fructose, depending on the enzyme source and/or production conditions (BANDLISH et al., 2002). These syrups are largely used in pharmaceutical applications as well as in food industries (VORAGEN, 1998). Although, such processes are consolidated, a large number of researches are conducting studies in order to decrease the production costs and find a new and economically attractive starch source for this process (SANJUST et al., 2004; VORAGEN, 1998; BANDLISH et al., 2002; SAUER et al., 2000; VAN DER VEEN; VAN DER GOOT; BOOM, 2005).

Cassava (Manihot esculenta), also called manioc, is a perennial plant widely grown in many tropical countries, including Brazil. Since cassava roots contain high starch content and low quantity of impurities such as protein and lipid, they are acknowledged as an excellent source of pure suitable starch for a wide range of applications (TONUKARI, 2004; SANGUANPONG et al., 2003).

This work describes a technology for glucose and fructose syrup production using Brazilian cassava starch and enzymes produced by soil microorganisms isolated from the Brazilian Cerrado soil.

\section{Materials and methods}

\subsection{Organisms, cultures and enzymes production}

Aspergillus niger was isolated from Cerrado soil samples and was indentified according to Gilman (1971). Briefly: $1 \mathrm{~g}$ of soil samples taken from the top $20 \mathrm{~cm}$ of the soil were dissolved in $10 \mathrm{~mL}$ of distilled water and serial dilutions were transferred to Petri plates containing Sabouraud agar (glucose $4 \%$, peptone $1 \%$, $\mathrm{CuSO}_{4} 0.001 \%$ and agar $1.5 \%$ ) and $500 \mathrm{mg} . \mathrm{L}^{-1}$ of penicillin. After inoculating the soil samples, the culture plates were incubated for 7 days at $30^{\circ} \mathrm{C}$. After growth, the fungal species were further isolated by dilution plate and single spore culture method and then subjected to taxonomic studies.

Streptomyces sp. strain was also isolated from the Cerrado soil sample according to Sanchez and Quinto (1975). First, the soil sample was dried at room temperature for about a week. After that, $1 \mathrm{~g}$ of this sample was mixed with $10 \mathrm{~mL}$ of sterile water and $100 \mu \mathrm{L}$ of this solution was spread out on Petri plates containing isolation medium (casein $0.04 \%$, starch $0.1 \%, \mathrm{KNO}_{3}$ $0.05 \%, \mathrm{KH}_{2} \mathrm{PO}_{4} 0.02 \%, \mathrm{MgSO}_{4} .7 \mathrm{H}_{2} \mathrm{O} 0.01 \%, \mathrm{CaCO}_{3} 0.01 \%$ and agar $1.5 \%$ ) supplemented with $500 \mathrm{mg} \cdot \mathrm{L}^{-1}$ of penicillin. The culture plates were incubated for 7 days at $30^{\circ} \mathrm{C}$. After growth, the species were subjected to taxonomic studies also according to Gilman (1971). Finally, the Streptomyces sp. strain was maintained in Yamanaka medium (xylose 1\%, glucose $1 \%$, peptone $1 \%$, sodium acetate $1 \%, \mathrm{MgSO}_{4} .7 \mathrm{H}_{2} \mathrm{O} 0.02 \%$, $\mathrm{MnSO}_{4} \cdot 6 \mathrm{H}_{2} \mathrm{O} 0.03 \%, \mathrm{CoCl}_{2} \cdot 6 \mathrm{H}_{2} \mathrm{O} 0.024 \%$ and agar $2 \%$ ).

For GA production, the spores $\left(10^{7} \cdot \mathrm{mL}^{-1}\right)$ were transferred to $500 \mathrm{~mL}$ of liquid medium consisting of yeast extract $1 \%$, $\mathrm{MgSO}_{4} .7 \mathrm{H}_{2} \mathrm{O} 1 \%, \mathrm{FeSO}_{4} 0.01 \%, \mathrm{CaCl}_{2} .2 \mathrm{H}_{2} \mathrm{O} 0.01 \%, \mathrm{KH}_{2} \mathrm{PO}_{4}$ $0.02 \%,\left(\mathrm{NH}_{2}\right)_{2} \mathrm{SO}_{4} 0.125 \%$ and starch $1 \%$. After incubation under constant shaking $(150 \mathrm{rpm})$ for 48 hours at $32{ }^{\circ} \mathrm{C}$, the culture supernatant was collected by filtration through Whatman $n^{\circ} 1$ paper and kept at $-20{ }^{\circ} \mathrm{C}$ until use.

For GI production, 8 discs of $5 \mathrm{~mm}$ in diameter from Streptomyces sp. culture plates were transferred to $500 \mathrm{~mL}$ of Yamanaka liquid medium. After incubation under constant shaking $(150 \mathrm{rpm})$ for 96 hours at $35^{\circ} \mathrm{C}$, the mycelium were harvested by filtration through filter paper Whatman $\mathrm{n}^{\circ} 1$, washed with $250 \mathrm{~mL}$ of $\mathrm{NaCl} 0.9 \%$, frozen in liquid nitrogen and stored at $-80{ }^{\circ} \mathrm{C}$ until use.

\subsection{Enzyme assays}

The GA activity was determined as previously described (SILVA; ASQUIERI; FERNANDES, 2005) by monitoring the starch hydrolysis. $60 \mu \mathrm{L}$ of enzyme solution was mixed with $40 \mu \mathrm{L}$ of $100 \mathrm{mM}$ sodium acetate buffer $\mathrm{pH} 4.2$ and $100 \mu \mathrm{L}$ of starch solution $0.5 \%(\mathrm{w} / \mathrm{v})$. The mixture was incubated at $60^{\circ} \mathrm{C}$ for 10 minutes. The amount of glucose released was determined at $510 \mathrm{~nm}$, using a glucose oxidase method (BERGMEYER; BERNT, 1974). One unit of GA corresponds to the amount of enzyme that released $1.0 \mu \mathrm{mol}$ of glucose per minute under the assay conditions.

As GI is an intracellular enzyme, all the procedures were carried out using the mycelium directly, according to Mirta et al. (1983). First, the enzyme was activated incubating $30 \mathrm{mg}$ of the previously obtained mycelium resuspended in $5.0 \mathrm{~mL}$ of distilled water at $50{ }^{\circ} \mathrm{C}$ for 10 minutes. Next, the sample was centrifuged at $6,000 \mathrm{rpm}$ for 10 minutes at $4{ }^{\circ} \mathrm{C}$. The supernatant was discarded and the cells were resuspended in $2.0 \mathrm{~mL}$ of Tris $\mathrm{HCl} 50 \mathrm{mM}$ buffer $\mathrm{pH} 8.0$ containing $\mathrm{MgSO}_{4} \cdot 7 \mathrm{H}_{2} \mathrm{O}$ $50 \mathrm{mM}, \mathrm{CoCl}_{2} .6 \mathrm{H}_{2} \mathrm{O} 0.25 \mathrm{mM}$ and $250 \mu \mathrm{L}$ of glucose solution $0.1 \mathrm{mg} \cdot \mathrm{mL}^{-1}$. For determining the GI activity, the system was incubated at $70^{\circ} \mathrm{C}$ for 30 minutes. The reaction was stopped with the addition of $2.5 \mathrm{~mL}$ of $\mathrm{HClO}_{4} 0.5 \mathrm{M}$. The fructose amount was determined using the cysteine-carbazol method proposed by Dishe and Borenfreud (1951). One unit of GI corresponds to the amount of enzyme that converts $1.0 \mu \mathrm{mol}$ of glucose per minute under the assay conditions.

\subsection{Determination of enzyme characteristics}

All enzymes characteristics, both GA and GI, were tested under previously described optimal testing conditions. The $\mathrm{pH}$ effect on the enzymes activity was determined by varying the $\mathrm{pH}$ of the reaction mixtures using $100 \mathrm{mM}$ of sodium citrate $(\mathrm{pH} 2.0-4.0), 100 \mathrm{mM}$ of sodium acetate $(\mathrm{pH} 4.2-5.5)$, $100 \mathrm{mM}$ of sodium phosphate $(\mathrm{pH} 6.0-8.0)$ and Tris $\mathrm{HCl}$ $50 \mathrm{mM}$ (pH 8.5-9.5) buffers supplemented with $\mathrm{MgSO}_{4} .7 \mathrm{H}_{2} \mathrm{O}$ $50 \mathrm{mM}$ and $\mathrm{CoCl}_{2} \cdot 6 \mathrm{H}_{2} \mathrm{O} 0.25 \mathrm{mM}$ when the GI was analyzed. The optimum temperature for the enzyme activities was from 0 to $100{ }^{\circ} \mathrm{C}$ for both enzymes and an additional $110^{\circ} \mathrm{C}$ point for the GI analysis. The thermal stability of GA enzymes was determined by incubating an enzyme solution for GA and mycelium suspension for GI at 50 and $60{ }^{\circ} \mathrm{C}$ and 60 and $70{ }^{\circ} \mathrm{C}$ for 180 minutes for GA and GI, respectively. At every 20 minutes, an appropriate aliquot of samples was taken out and used to analyze the enzymes as described above. Kinetic parameters $\left(\mathrm{K}_{\mathrm{M}}\right.$ and $\left.\mathrm{V}_{\max }\right)$ were determined at best conditions for 
the enzymatic analysis by measuring the initial reaction yields with soluble starch at various concentrations (1-25 mg.mL ${ }^{-1}$ ) for GA and for glucose solution at various concentrations (1-100 $\left.\mu \mathrm{g} \cdot \mathrm{mL}^{-1}\right)$ for GI. The constant values were calculated using the software Microcal-Origin 5.0.

\subsection{Production of glucose syrup}

For the glucose syrup production, a suspension of $35 \%$ $(\mathrm{w} / \mathrm{v})$ of previously extracted cassava starch was prepared. The suspension $\mathrm{pH}$ was adjusted using $0.2 \mathrm{M} \mathrm{pH} 6.0$ phosphate buffer. This suspension was maintained under heating, increasing the temperature in $1{ }^{\circ} \mathrm{C} /$ minute, until the starch was completely solubilized. After, it was cooled down, the solution was incubated in water bath at $50{ }^{\circ} \mathrm{C}$ with $10 \mathrm{~mL}$ of commercial a-amylase Sigma ${ }^{\circledast}\left(1 \mathrm{mg} \cdot \mathrm{mL}^{-1}\right)$ for 2 hours for total liquefaction. For scarification, this resulting maltodextrin syrup had its $\mathrm{pH}$ adjusted to 4.2 with $0.2 \mathrm{M}$ of acetate buffer. Then, $100 \mathrm{~mL}$ of previously produced and characterized glucoamylase solution was added and incubated at $60^{\circ} \mathrm{C}$ for 48 hours under constant agitation. The glucose production was monitored using the glucose oxidase method as before. After this process, the resulting syrup was purified by ion exchanged chromatography using Amberlite Ira 120 (Cationic resin) and Amberlite Ira 410 (Anionic resin) and then concentrated by evaporation under reduced pressure.

\subsection{Production of fructose syrup}

The production of fructose syrup was carried out using previously obtained glucose syrup. The solution had its $\mathrm{pH}$ adjusted to $\mathrm{pH} 8.0$ with $0.2 \mathrm{M}$ Tris- $\mathrm{HCl}$ buffer containing $\mathrm{MgSO}_{4} \cdot 7 \mathrm{H}_{2} \mathrm{O} 50 \mathrm{mM}$ and $\mathrm{CoCl}_{2} \cdot 6 \mathrm{H}_{2} \mathrm{O} 0.25 \mathrm{mM}$. Differently of glucose syrup production, the isomerization was performed using Streptomyces mycelium instead of the enzyme solution. For that, $30 \mathrm{~g}$ of Streptomyces sp. Mycelium was fastened to dialysis bags to avoid contaminating the solution. The system was incubated under constant agitation at $70{ }^{\circ} \mathrm{C}$ for 96 hours. The fructose production was monitored using the cysteinecarbazol method proposed by Dishe and Borenfreud (1951), as before. Next, the resulting fructose syrup was purified and concentrated as glucose syrup.

\section{Results and discussion}

Figure 1 shows the $\mathrm{pH}$ effect on the enzyme activity. GA exhibits a good activity, ranging from pH 3.0 to 5.5 and its optimal $\mathrm{pH}$ is 4.5 . GI showed maximal activity at $\mathrm{pH}$ 8.0. The optimum $\mathrm{pH}$ range of GI is generally between $\mathrm{pH} 7.0$ and 9.0. However, GI exhibited activity above $70 \%$ in the $\mathrm{pH}$ range of 6.0 to 8.0 which is desirable for commercial applications of GI (SNEHALATA; BHOSALE; VASANTI, 1996).

Figure 2 shows the optimum temperature profiles for the enzymes. GA presented maximum activity at $60{ }^{\circ} \mathrm{C}$. The industrial applications of glucoamylases require temperatures at around $60-70{ }^{\circ} \mathrm{C}(\mathrm{FORD}, 1999)$. This finding is in agreement with other reported works for GA from Aspergillus niger (SILVA; ASQUIERI; FERNANDES, 2005). The optimum temperature for GI was $85{ }^{\circ} \mathrm{C}$. The optimum temperature for GI ranges from 60 to $80{ }^{\circ} \mathrm{C}$ and can increase in the presence of $\mathrm{Co}^{2+}$. The glucose isomerase from Streptomyces spp., Bacillus spp., Actinoplanes missouriensis, and Thermus thermosulfurogenes shows high optimum temperatures $\left(70-90^{\circ} \mathrm{C}\right)$ while that from Lactobacillus and Escherichia spp. shows low temperatures (37-50 $\left.{ }^{\circ} \mathrm{C}\right)$ (BANDLISH et al., 2002; SNEHALATA; BHOSALE; VASATI, 1996).

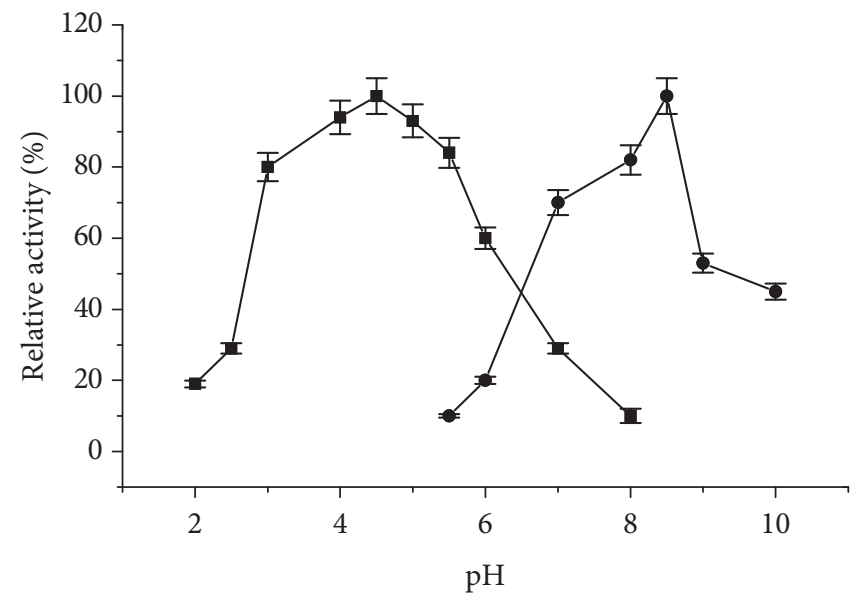

Figure 1. Effect of $\mathrm{pH}$ on the activity of glucoamylase (-) and glucose isomerase $(\bullet)$. GA and mycelium of Streptomyces sp. (GI) were incubated with different buffers, $100 \mathrm{mM}$ of sodium citrate ( $\mathrm{pH} 2.0-4.0$ ), $100 \mathrm{mM}$ of sodium acetate ( $\mathrm{pH} 4.2-5.5), 100 \mathrm{mM}$ of sodium phosphate (pH 6.0-8.0) and Tris $\mathrm{HCl}$ of $50 \mathrm{mM}(\mathrm{pH} 8.5-9.5)$ under standard condition of activity for both enzymes. The buffers were supplemented with $\mathrm{MgSO}_{4} .7 \mathrm{H}_{2} \mathrm{O} 50 \mathrm{mM}$ and $\mathrm{CoCl}_{2} \cdot 6 \mathrm{H}_{2} \mathrm{O} 0.25 \mathrm{mM}$ for the analysys of GI. All tests were performed in triplicate and the results showed average and standard deviation.

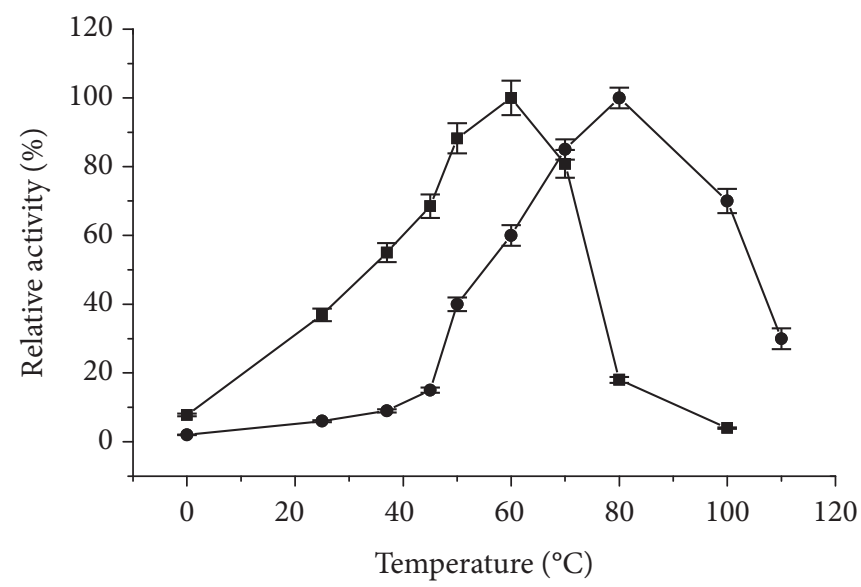

Figure 2. Temperature effect on the activity of glucoamylase $(\bullet)$ and glucose isomerase $(\bullet)$. GA and mycelium of Streptomyces sp. (GI) were incubated at different temperatures under standard conditions and the enzymatic activity was determined. All tests were performed in triplicate and the results were average and standard deviation. 
The thermal stability of enzymes was also investigated by incubating the enzymes at 50 and $60{ }^{\circ} \mathrm{C}$ and 60 and $70{ }^{\circ} \mathrm{C}$ for GA and GI, respectively, for 180 minutes prior to the analysis of the enzyme. After 1 hour of incubation at $60{ }^{\circ} \mathrm{C}$ the GA retained approximately $65 \%$ of its initial activity, whereas GI retained approximately $80 \%$ (data not shown). This finding is interesting because an energy reduction and lower times to cool the reaction mixture represents advantages for industries process applications (SANJUST et al., 2004; SNEHALATA; BHOSALE; VASATI, 1996).

The Michaelis-Menten constant $\left(\mathrm{K}_{\mathrm{M}}\right)$ and the maximum reaction rate $\left(\mathrm{V}_{\text {máx }}\right)$ are important parameters for the characterization of any enzyme. These parameters are fundamental to choosing the enzymes for large scale industrial applications (SILVA; ASQUIERI; FERNANDES, 2005). After determining the optimum conditions for GA and GI activity, the kinetic parameters of $\mathrm{k}_{\mathrm{m}}$ and $\mathrm{V}_{\text {max }}$ for both enzymes were determined. GA showed $\mathrm{k}_{\mathrm{M}}$ and $\mathrm{V}_{\text {máx }}$ values of $0.476 \pm 0.021\left(\mathrm{mg} \cdot \mathrm{mL}^{-1}\right)$ and $8.58 \pm 0.047$ ( $\left.\mu \mathrm{mol} / \mathrm{minute}\right)$ respectivly. The GA $\mathrm{k}_{\mathrm{M}}$ values depend intrinsically on the substrate, if starch or maltose were used. Since starch was used, this is according to the literature (POLAKOVIC; BRYJAK, 2004). The conversion ratios of $\mathrm{D}$-glucose to $\mathrm{D}$-fructose catalyzed by GI from various organisms in soluble or immobilized form are in the range of 26 to $59 \%$. The $\mathrm{Km}$ value of GI for D-glucose is in the range of 0.086 to $0.920(\mathrm{M})$ (CHEN, 1980). GI showed $0.082 \pm 0.003(\mathrm{M})$ for $\mathrm{k}_{\mathrm{M}}$ value and $48.20 \pm 0.200(\mu \mathrm{mol} /$ minute) for $\mathrm{V}_{\text {máx }}$. The low value found for GI $\mathrm{k}_{\mathrm{M}}$ is be explained by the fact that here the mycelium of Strpetomyces sp. was used directly, instead of the enzyme solution and factors such as the transporter of glucose should be included in the calculation of the final $\mathrm{k}_{\mathrm{M}}$ value, however, this is not the objective of this work. In any case, this $\mathrm{k}_{\mathrm{M}}$ value could be used as a parameter for fructose syrup production without problems.

Figure 3 shows the conversion of cassava starch in glucose. The maximum conversion occurred after 24 hours of reaction and no significant difference was observed after that. Most works report that this conversion rate is reached only after 48 hours of reaction (PARK; PAPINI, 1970; CADMUS; HENSLEY, 1996; AKERBERG et al., 2000; TANRISEVEN; ULUDAG; DOGAN, 2002), indicating that the GA produced by $A$. niger isolated from Cerrado soil has high affinity with cassava starch. This finding is interesting for industrial applications since costs can be reduced. Higher conversion rates are not reported in the literature due to the irregular structure of starch (TANRISEVEN; ULUDAG; DOGAN, 2002).

Figure 4 shows the isomerization rate of glucose during the glucose to fructose conversion. The results revealed that the maximum isomerization rate occurred after 96 hours of reaction with approximately $42 \%$ of conversion. The reaction of glucose to fructose conversion has a constant equilibrium value of 1 , which means that the maximum rate of isomerization reaction that can be obtained is of about $50 \%$. Syrups with high fructose content above $42 \%$ produced from corn, such as HFC-55 or HFC-90, can be reached either by chromatography concentration or by evaporation under reduced pressure (BLANCHARD; GEIGER, 1984). Vissuri and Klibavov (1987) reported on the production of fructose syrup with $55 \%$ of fructose, working with the fructose solubility in ethanol and then dislocating the reaction equilibrium, resulting in increased fructose content.

The results presented in this paper indicate that the GA and GI produced by A. niger and Streptomyces sp., respectively, are attractive candidates for industrial applications. Further experiments of co-immobilization using both enzymes or both mycelia may provide strategies to improve the characteristics of these enzymes and enable their use in large-scale glucose and fructose syrup production from cassava starch.

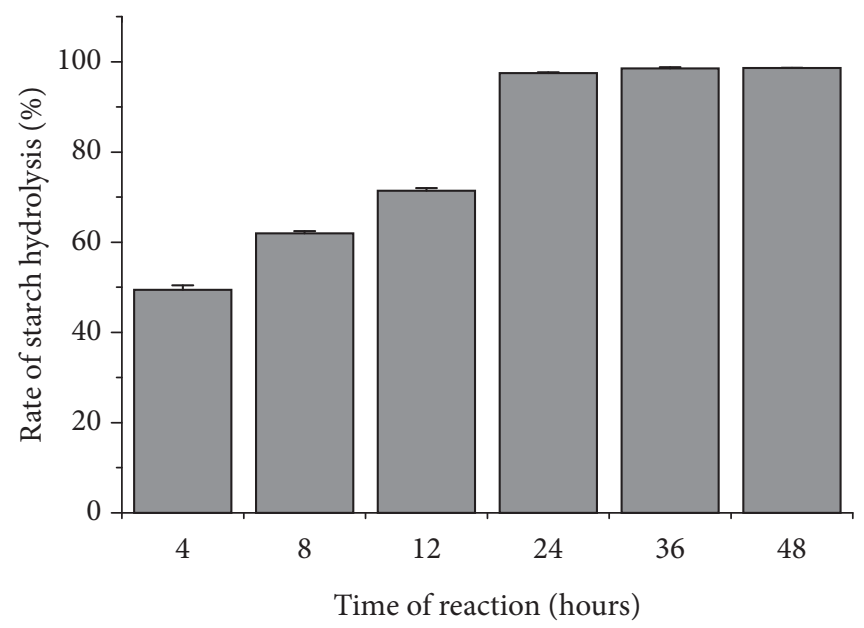

Figure 3. Time course of glucose syrup production from cassava starch. Maltodextrin solution previously obtained from cassava starch using commercial $\alpha$-amylase was incubated with GA from $A$. niger for 48 hours. The formation of glucose was monitored using the glucose oxidase method at different times. All tests were performed in triplicate and the results were average and standard deviation.

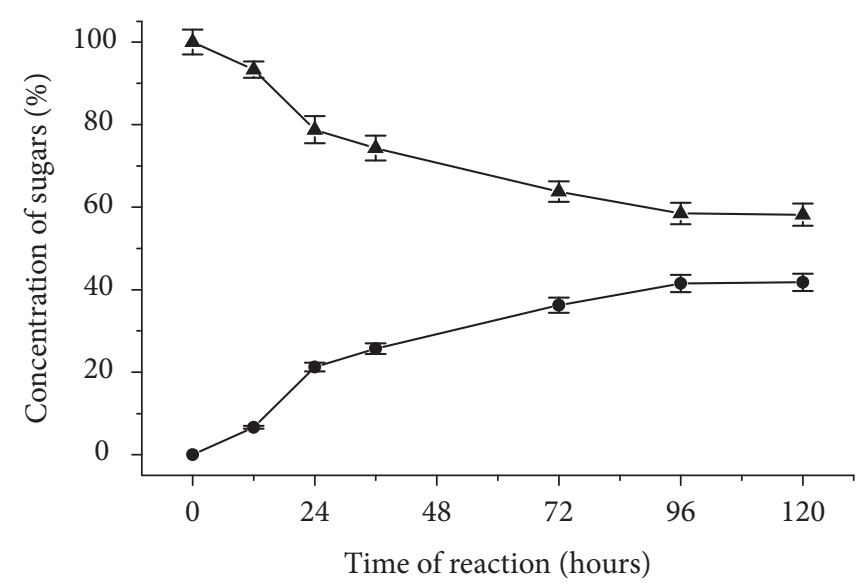

Figure 4. Time course of fructose syrup from glucose syrup of cassava starch. The glucose syrup resulted from early step was incubated with mycelium of Streptomyces sp. for 120 hours. The production of fructose was monitoring using the cysteine-carbazol method at different times. All tests were performed in triplicate and the results were average and standard deviation. ( $\bullet$ ) Glucose consumption and (•) Fructose formation. 


\section{Conclusions}

We conclude that the enzymes, glucoamylase, produced by A. niger and, glucose isomerase, produced by Strpetomyces sp., both isolated from Brazilian Cerrado soil showed biochemical characteristics, such as optimum $\mathrm{pH}$ and temperature and as well good thermal stability, that can be used in industrial process as starch processing. Furthermore, the technology used for glucose and fructose syrup production using Brazilian cassava starch and enzymes produced by soil microorganisms was successful and can be up scaled for industrial purpose.

\section{References}

AKERBERG, C. et al. A kinetic model for enzymatic wheat starch saccharification. Journal of Chemical Technology and Biotechnology, v. 75, n. 4, p. 306-314, 2000.

BANDLISH, R. K. et al. Glucose-to-fructose conversion at high temperatures with xylose (glucose) isomerases from Streptomyces murinus and two hyperthermophilic Thermotoga species. Biotechnology and Bioengineering, v. 80, n. 2, p. 185-194, 2002.

BERGMEYER, H. U.; BERNT, E. Determination of glucose with oxidase and peroxidase. Methods in Enzymology, v. 3, p. 1205-1215, 1974.

BLANCHARD, P. H.; GEIGER, E. D. Production of high fructose corn syrup in the USA. Sugar Technology Review, v. 11, n. 1, p. 1-94, 1984

CABELLO, C. Amylases using in glucose syrup production. In: SEMINÁRIO BRASILEIRO DE TECNOLOGIA ENZIMÁTICA ENZITEC, 4, 1999, Rio de Janeiro. Anais... v. 1, p. V1-V3.

CADMUS, M. C.; HENSLEY, J. D. E. Enzymatic production of glucose syrup from grains and its use in fermentations. Cereal Chemistry, v. 43 , p. $658-669,1966$.

CHEN, W. P. Glucose isomerase. Process Biochemistry, v. 15, n. 5, p. $36-41,1980$

DISHE, Z.; BORENFREUD, E. A new espectrophotometric method for the detection and determination of keto sugars and trioses. The Journal of Biological Chemistry, v. 192, n. 2, p. 583-587, 1951.

FORD, C. Improving operating performance of glucoamylase by mutagenesis. Current Opinion in Biotechnology, v. 10, n. 4, p. 353-357, 1999.

GILMAN, J. C. A. Manual of Soil Fungi. 2 ed. Iowa: Iowa State College Press, 1971. p. 450.

MIRTA, M. F. et al. Producción de glucosa-isomerasa por Streptomyces phaeochromogenes. Revista Argentina de Microbiología, v. 15, n. 1, p. 1-8, 1983.

PARK, D. et al. Immobilization of starch-converting enzymes on surface-modified carriers using single and co-immobilized systems: properties and application to starch hydrolysis. Process Biochemistry, v. 40, n. 1, p. 53-61, 2005.

PARK, Y. K.; PAPINI, R. S. Glucose syrup production from cassava starch by enzyme-enzyme method. Coletânea do Instituto de Tecnologia de Alimentos, v. 3, p. 65-74, 1970.

POLAKOVIC, M.; BRYJAK, J. Modelling of potato starch saccharification by an Aspergillus niger glucoamylase. Biochemical Engineering Journal, v. 18, n. 1, p. 57-63, 2004.

PONTOH, J.; LOW, N. H. Glucose syrup production from Indonesian palm and cassava starch. Food Research International, v. 28, n. 4, p. 379-385, 1995.

SANCHEZ, S.; QUINTO, C. M. D-Glucose Isomerase: constitutive and catabolite repression-resistant mutants of Streptomyces phaeochromogenes. Applied Microbiology, v. 30, n. 5, p. 750-754, 1975.

SANGUANPONG, V. et al. Hydration and physico-chemical properties of small-particle cassava starch. Journal of the Science of Food and Agriculture, v. 83, n. 2, p. 123-132, 2003.

SANJUST, E. et al. Xylose production from durum wheat bran: enzymic versus chemical methods. Food Science and Technology International, v. 10, n. 1, p. 11-14, 2004.

SAUER, J. et al. Glucoamylase: structure/function relationships, and protein engineering. Biochimica et Biophysica Acta, v. 1543, n. 2, p. 275-293, 2000.

SCHENCK, F. W.; HEBEDA, R. E. Starch hydrolysis products: worldwide technology, production and applications. New York: VCH Publishers, 1992.

SILVA, R. N.; ASQUIERI, E. R.; FERNANDES, K. F. Immobilization of Aspergillus niger glucoamylase onto a polyaniline polymer. Process Biochemistry, v. 40, n. 3-4, p. 1155-1159, 2005.

SNEHALATA, H.; BHOSALE, M. B. R.; VASANTI, V. D. Molecular and industrial aspects of glucose isomerase. Microbiology Review, v. 60 , n. 2 , p. $280-300,1996$

TANRISEVEN, A.; ULUDAG, Y. B.; DOGAN, S. A novel method for the immobilization of glucoamylase to produce glucose from maltodextrin. Enzyme and Microbial Technology, v. 30, n. 3, p. 406-409, 2002.

TONUKARI, J. N. Cassava and the future of starch. Electronic Journal of Biotechnology, v. 7, n. 1, p. 1-8, 2004.

Van der VEEN, M. E.; Van der GOOT, A. J.; BOOM, R. M. Production of glucose syrups in highly concentrated systems. Biotechnology Progress, v. 21, n. 2, p. 598-602, 2005.

VISURI, K.; KLIBAVOV, A. M. Enzymatic production of high fructose corn syrup (HFCS) containig 55\% fructose in aqueous ethanol. Biotechnology and Bioengineering, v. 30, p. 917-920, 1987.

VORAGEN, A. G. J. Technological aspects of functional food-related carbohydrates. Review. Trends in Food Science and Technology, v. 9, n. 6, p. 328-335, 1998. 